\title{
ACADEMIC FREEDOM AND ITS CONSTRAINTS: A COMPLEX HISTORY
}

\author{
PAUL AXELROD \\ YORK UNIVERSITY
}

\section{Abstract}

Academic freedom has a long, complex history in Canada and elsewhere. For reasons that are at times justifiable and at times indefensible, academic freedom has been constrained in a variety of ways, and not only by institutional or political authorities. Using illustrations drawn from Canada and beyond, this article tracks the history and progress of academic freedom and takes stock of its status in the first part of the 21st century. It explores the origins of academic freedom, the evolving ways in which it has been qualified and even impeded, the particularity of Canadian approaches to its values and practices, and the ongoing challenges universities may face sustaining academic freedom in unsettled and unpredictable times.

Keywords: academic freedom, university history, Canadian higher education

\section{Résumé}

La liberté académique a une histoire longue et complexe au Canada et ailleurs. Pour des raisons parfois justifiables et parfois indéfendables, la liberté académique a été limitée de diverses manières, et pas seulement par les autorités institutionnelles ou politiques. À l'aide d'illustrations tirées du Canada et d'ailleurs, cet article retrace l'histoire et les progrès de la liberté académique et fait le point sur son statut dans la première partie du 21 siècle. Il explore les origines de la liberté académique, les manières changeantes dont elle a été qualifiée et même entravée, la particularité des approches canadiennes quant à ses valeurs et pratiques, et les défis auxquels les universités peuvent être confrontées pour maintenir la liberté académique en des temps instables.

Mots-clés : liberté académique, histoire de l'université, enseignement supérieur canadien

\section{Introduction}

Academic freedom has a long, complex history in Canada and elsewhere. It has largely been experienced and studied as the struggle by professors to obtain and preserve intellectual autonomy in the face of coercion by administrative authorities within the university and by political authorities outside the university. While these dynamics are a huge part of the story of academic freedom, and of the history of the university itself, they are by no means the whole story. For reasons that are at times justifiable and at times indefensible, academic freedom has been constrained in a variety of ways, and not only by institutional or political authorities. Using illustrations drawn from Canada and beyond, this article tracks the history and progress of academic freedom and takes stock of its status in the first part of the 21st century. ${ }^{1}$ It explores the origins of academic freedom, the evolving ways in which it has been qualified and even impeded, the particularity of Canadian approaches to its values and practices, and the ongoing challenges universities may face sustaining academic freedom in unsettled and unpredictable times.

\section{Foundations}

The contemporary western university has its origins in Europe in the Middle Ages, though higher learning itself 
has much deeper roots that extend well beyond Europe. Chinese, Indian, and Egyptian scholars and scribes, not to mention those illustrious thinkers of ancient Greece and Rome, contributed to philosophical and scientific thought long before the founding of the Universities of Bologna, Oxford, and Paris (Domonkos, 1977; Kimball, 1995).

By the fifteenth century the universitas-a community of scholars-had been established throughout Europe and functioned under papal authority. A form of academic freedom existed in practice, if not in theory. There were deep debates over theology and philosophy that consumed the intellectual energies of medieval scholars. Faith in God was a given, and the learning of received religious texts was essential. Was there room for critical thinking and analysis within this Catholic intellectual universe?

Peter Abelard, a Parisian teacher and philosopher in the early 12th century, thought so. He argued that logic ought to be used in the contemplation of Christian doctrine; in this way, faith could coexist with reason and reflection. Some of Abelard's contemporaries disagreed and sought to silence him; he was hounded and exiled throughout his academic career. He was also castrated by relatives of Eloise, a former student, with whom he had an affair (Clanchy, 1997). Medieval higher education certainly fostered debate, but there were clear limits to an academic's freedom (Courtenay, 1989).

Inspired by classical Greek thought, some Renaissance writers and artists sought to free scholarship from conventional restraints in order to explore the full range of human beliefs and actions, but universities remained, for the most part, unreceptive to such pleas, as the conviction of Galileo for heresy demonstrated. The Protestant Reformation broadened the parameters of acceptable religious inquiry but still imposed strict theological limits on academic teaching and writing.

Doors opened considerably to scientific thought and critical inquiry during the Enlightenment. Scottish universities were especially receptive to newer philosophical perspectives by such scholars as David Hume, whose skeptical thinking challenged both theological and recent materialist ideas about the nature of reality. But such tolerance was not universal and not all Enlightenment intellectuals-or their ideas-were welcomed in the halls of higher learning. When, in the early 1700 s, Yale senior students sought to circulate John Locke's Essay Concerning Toleration (Locke, 2006), the uni- versity president "reprimanded them and insisted that, under penalty of forfeiting their degrees, they make a public confession of their sin in undertaking the project" (Brubacher \& Rudy, 1976, p. 309). American faculty and students who challenged slavery or who took other subversive positions were also at risk in the post-Enlightenment era.

It should be noted, however, that champions of religious colleges and universities, past and present, have believed that academic freedom cannot only be reconciled with their institutions' missions, but strengthened by them as well. Charles L. Glenn (2010) writes:

Teaching is not a solitary enterprise.... Medieval universities were corporate bodies of professors who could take for granted, in large measure, a common worldview and a common faith, who joined at great occasions in common liturgies - how difficult it is today, in a great university, to persuade the faculty to come together for any occasion!... We have no common ground on which to meet, even to quarrel. Surely the freedom of a professor to teach is enhanced if he can teach within a shared framework of meaning, sustained by what colleagues have taught and will teach. (p. 20)

Thus, one academic's model for pursuing knowledge and truth-which includes deference to authority and prescribed behavioural norms-is another's version of dogmatism and restraint, a reality that can confound the academic freedom debates. Think, for example, of the recent case at Trinity Western Law School, an evangelical Christian university in British Columbia, whose original "community covenant" required faculty and students to abide by strict moral and religious codes, including a prohibition on same-sex relations ${ }^{2}$ (Harris, 2018; MacKinnon, 2018).

The 19th century witnessed extensive change in the development of higher education. Church-led universities endured, especially in North America, but state-funded, non-denominational colleges spread rapidly throughout Europe and the United States, and, to a lesser extent, in England. In an era of intense nationalistic rivalries, higher education, more than ever, was intended to serve the cause of nation-building, both in the highly centralized systems of France and Germany and in the relatively decentralized American and Canadian systems. 
In the German case, particularly at Humboldt University (established in 1809), two cornerstones of contemporary university life were legitimated: specialized research and academic freedom. The latter permitted students and faculty to pursue scholarly life unimpeded, so long as they avoided political dissidence by challenging the authority of the state. Professorial autonomy was thus extended but still conditional.

\section{Constraints}

In the early 20th century, as industrialization fuelled the expansion of universities' economic and social roles, they depended increasingly on private and public funding sources; the latter were especially important in Canada. Could academics openly criticize their institutions' leaders, patrons, or sponsors? Most university presidents said no, an attitude that led to considerable conflict and to the formation of the American Association of University Professors in 1915 (Fallis, 2007; Tiede, 2015).

The concern for moral and intellectual order informed the purposes and regulations of Canadian universities in the first half of the 20th century. University of Toronto historian George Wrong claimed in 1931 that "in the main the universities of the western world are strongholds of conservative thought and a steadying influence on our society. This is not less true of McGill and Toronto than of Oxford and Cambridge" (Horn, 1980, p. 182). While this era produced a number of extraordinary university scholars, qualifications on academic expression were palpable. Sir Edward Beatty, Chancellor of McGill, wrote a lengthy article on academic freedom, which on one hand defended freedom of thought as sacred, and on the other claimed that there were "limits within which these liberties may be exercised and that to exceed [them] was not only foolish but wrong" (Beatty, 1937, p. 467). He contended that the university must be accountable to its sponsors. If students were taught incorrectly, then "outside the university walls there may well be men competent to detect these errors. Every such case reflects discredit on the university and shakes public confidence" (Beatty, 1937, p. 467).

Provoking political authorities or donors was one academic sin; promoting the cause of socialism in a world worried about the prospects of insurgent Bolshevism was another. Two McGill professors, including future senator and constitutional expert Eugene Forsey, were let go for these reasons, and historian Frank Underhill, who criticized Canadian foreign policy before and during World War II, barely held on to his position at the University of Toronto (Horn, 1999). In addition, the Royal Canadian Mounted Police, at times with the approval of university authorities, conducted surveillance on leftwing faculty and students throughout this period and well beyond (Axelrod, 1995; Hewitt, 2002).

Academic voices were contained and excluded in other ways. Reflecting and perpetuating dominant social prejudices, Canadian universities almost never hired Jews, and several imposed quotas on the admission of Jewish students during the 1930s and 1940s. People of colour were virtually absent, and women, if hired at all, were paid little and rarely promoted (Axelrod, 1990). Canadian universities, including the non-denominational ones, were culturally, religiously, ideologically, and demographically homogenous before the 1960 s. Academic freedom, available only to those from favoured groups who could access the academy, was both recognized and constrained.

Such constraints were challenged, increasingly successfully, in the wake of the social and cultural changes that swept through higher education in the 1960s. Student activists insisted on the full right to free expression, greater curricular choice, deeper involvement in university governance, and the responsibility of universities themselves to promote social justice both inside and outside their walls (Campbell et al., 2012). Faculty obtained more authority through university senates, stronger academic freedom provisions, and clearer protocols with respect to hiring, tenure, and promotion, all fortified by new collective bargaining agreements across the country. The Canadian Association of University Teachers, founded in 1951, assertively took up the cause of academic freedom in the wake of the Harry Crowe case at United College in Winnipeg in 1958. Crowe was fired (and eventually reinstated) for criticizing the president of the college in a private letter (Cameron, 1991; Gidney, 2012; Horn, 1999). The right of Canadian professors to publicly challenge their institutions' policies became embedded in the universities, an entitlement not normally available to employees of other public and private organizations (Governing Council, University of Toronto, 2016). While academic freedom "has very limited statutory or constitutional recognition in Canada" (Robinson, 2019, para. 1), collective bargaining agreements, which now cover most full-time professors in the country, have played a critical role in securing and sustaining academ- 
ic freedom provisions. This is not the case in the United States, where academic freedom protections flow largely from court interpretations of First Amendment rights in the American constitution (Robinson, 2019).

Systemic bigotry was addressed, if not eliminated, by federal and provincial human rights legislation, including, eventually, a Charter of Rights and Freedoms, which prohibited discrimination on the basis of gender, race and religion ${ }^{3}$ (Cromwell, 2020; Rogers et al., 2018). By most measures, the autonomy and security of $\mathrm{Ca}$ nadian academics were enhanced in the last half of the 20th century, even in light of a number of contentious cases that tested the boundaries of faculty rights and university authority in this era (Horn, 1999).

The CAUT's (2018) updated statement on academic freedom offered an expansive conception of faculty entitlements. It asserted that

Academic freedom includes the right, without restriction by prescribed doctrine, to freedom to teach and discuss; freedom to carry out research and disseminate and publish the results thereof; freedom to produce and perform creative works; freedom to engage in service; freedom to express one's opinion about the institution, its administration, and the system in which one works... (para. 2)

Had scholarly nirvana finally arrived? Was academic freedom now genuinely unconditional?

Not really. While much of Universities Canada's (formerly AUCC) conception of academic freedom closely resembled that of the CAUT's, it included a section on the "Responsibilities of Academic Freedom," with terms that pertain today.

Academic freedom is constrained by the professional standards of the relevant discipline and the responsibility of the institution to organize its academic mission. The insistence on professional standards speaks to the rigor of the enquiry and not to its outcome.... The constraint of institutional requirements recognizes simply that the academic mission, like other work, has to be organized according to institutional needs. This includes the institution's responsibility to select and appoint faculty and staff, to admit and discipline students, to establish and control curriculum, to make organizational arrangement for the conduct of academic work, to certify completion of a program and to grant degrees. (Universities Canada, 2011, para. 7)

This means that professors are not free to teach anything they want. Courses must be vetted and approved by departmental committees composed of one's colleagues, and to get one's course adopted, a professor may have to alter the content. Furthermore, to satisfy student or programmatic needs, faculty may be compelled to teach courses they would rather not.

Consider as well that faculty cannot publish in scholarly outlets anything and everything they research and write. They are subject to peer review, and their voices could well be muted by assessors and journal editors who, theoretically, are the gatekeepers of scholarly standards. Journals themselves may have certain conceptual or traditional orientations unfriendly to the work of new or innovative scholars. Peer review is central to the world of academic publishing but the process is far from foolproof (Axelrod, 1999), and in the age of the internet, where bogus journals abound, and where, increasingly, authors must pay publishers for the privilege of having articles appear in journals (something that was once called vanity publishing), sustaining meaningful standards is harder than ever. It remains to be seen how these developments will affect the exercise of academic freedom.

Academic freedom, it should be stressed, is not identical to freedom of speech, even though the two concepts are frequently conflated. In the classroom, university teachers must lecture competently; they do not have a licence to use their podiums in order to propagandize, speak in habitually ill-informed ways, or lie (Ben-Porath, 2017). Free speech allows citizens to do this on street corners or through blogs, but universities have loftier goals. In order to uphold professional standards, professors' teaching and research are subject to peer assessment; ordinary citizens' words are not, though they too are limited by certain restraints such as libel and hate speech laws. Academic freedom and freedom of speech are different forms of expression, both vital, in a democratic society.

The post-1960s pursuit of social justice and equality for historically marginalized populations, to which many in universities were (and remain) committed, required the consideration of group as well as individual interests-a tension that is continuously addressed outside universities (by law and regulation) in liberal democratic societies (Kymlicka, 1995). In the past, collective rights- 
the privileging of men and Christians over women and non-Christians in universities-protected the social advantage of dominant groups; in the contemporary period, collective or group rights are intended to enhance the equal and just treatment of all. Philosophers Will Kymlicka, Charles Taylor, and Martha Nussbaum have provided influential explanations and justifications for the use of such policy instruments, as did the 1984 Royal Commission Report, Equality in Employment, by Justice Rosalie Abella. Individual and group rights in liberal democratic societies, they have argued, can be reconciled (Abella, 1984; Nussbaum, 1997; Taylor, 1994). Affirmative action and employment equity programs in universities and elsewhere became legitimate legal tools in the pursuit of equality for individuals, and for the identified groups of which they are members. "Academic freedom is the inclusive university," argued Drakich and colleagues in 1995 (Drakich et al., 1995, p. 118). Institutions, they contended, should not only be required to open their doors to the historically marginalized, but they must cultivate a teaching and learning environment that is conscious and respectful of the identities and perspectives of an increasingly diverse community. They wrote, "At the core of the truly inclusive university is a culture of academic freedom that will welcome changing pedagogies, fields, and university populations and promote equality" (Drakich et al., 1995, p. 120). This is a critically important context in which academic freedom debates are conducted and, often uncomfortably, played out (Ben-Porath, 2017). The numerous conflicts on North American campuses since the 1980s, over what has come to be called political correctness-the contentious use of language or practices that offend sensibilities, often around sex or race-indicate how fraught the academic freedom debates can still be (Horn, 1999).

\section{Ideology}

Key threats to academic freedom, tolerance, and civil discourse today come from two forces on opposite ends of the ideological spectrum. On the left are some who seek to silence individuals considered enemies of equity, which, as l've suggested, is increasingly deemed to be a core value of higher education. Such tactics were not unknown in the 1960s, and one episode is worth recalling.

In 1969, Clark Kerr, former president of the Univer- sity of California, who had been fired by Governor Ronald Reagan for "allegedly being soft in his dealings with student [radicals]" (Friedland, 2002, p. 533), was invited to speak at the University of Toronto. Because he was a proponent of the "multiversity with its links to business, government and the military" (Friedland, 2002, p. 533), he aroused the wrath of some New Left activists who took over the stage and interrupted his speech. Following ad hoc negotiations, where two of the protesters were themselves permitted to speak, Kerr completed his address. The two interrupters, incidentally, became tenured professors, and one of the negotiators was Bob Rae, who became premier of Ontario in 1990 (Friedland, 2002).

This incident, jolting as it was, paled in comparison to confrontations in 2018 at Berkeley, involving conservatives Milo Yiannopoulos and Ann Coulter, whose scheduled speeches were cancelled because of violence and threats of further violence if the events went ahead (Gursen, 2017; Quantana, 2017a). A planned speech by Coulter at the University of Ottawa in 2010 had been similarly cancelled in light of security concerns (Chase, 2010), as was a scheduled talk at Concordia University by Israeli Prime Minister Benjamin Netanyahu in 2002 ("Montreal protestors force cancellation," 2002). Campus activism in the 1960 s justifiably removed most restraints on campus speech, but some militant students sought to limit the voices of those who did not share their social change or social justice agendas, something we have witnessed again in recent years.

In March of 2018, attempts were made to keep Jordan Peterson, the controversial University of Toronto psychologist, from speaking at Queen's University. The principal [president] of Queen's ensured that the event went on. Some 800 people attended, so there was obvious interest in Peterson's talk. There is a video of one of the protestors outside the building, just as the talk was about to begin, saying, jokingly, yet still shockingly, "Let's lock them in and burn it down" ("Jordan Peterson protest," 2018, p. 1). Demonstrators also banged on the windows and broke one in an attempt to keep Peterson from being heard.

In such cases then, militant students and their supporters, driven by a sense of combative idealism, threaten to constrain academic voices on ideological grounds. Incidents of de-platforming, in which invited speakers are dis-invited, or interrupted during their presentations, 
have erupted periodically in various countries. According to some critics, cancel culture-the public boycotting or silencing of individuals whose ideas are deemed offensive-is the new norm in higher education (Chaudry \& Kennedy, 2020; Kaufman, 2020).

The other threat to the university's core values comes from the far right by advocates, some of whom, in the name of freedom of speech, oppose all restraints on expression. By this logic, racist and sexist language should be permitted on campus and any effort to control such speech is nothing more than political correctness gone awry (Dreid \& Najmabadi, 2016)-except that some of these critics, hypocritically, seek also to muzzle voices they deplore. Alt-right supporters in the United States, on and off campus, have demonized some academic critics of former U.S. president Donald Trump. In 2017, Keeanga-Yamahtta Taylor, an assistant professor of African-American studies at Princeton University, indelicately described Trump in a commencement speech at Hampshire College as "a racist, sexist, megalomaniac" (Flaherty, 2017a, para. 1). She was advised to stay away from campus in light of the vile email and death threats she received (Thrasher, 2017).

Another right-wing campaign has sought to out liberal and leftist professors on a website called Campus Reform. Trinity College in Connecticut was forced to shut down for a day in June of 2017 because of threats directed at one of its faculty members who was accused by Campus Reform, inaccurately as it turns out, of favouring the death of white people. While the professor used a foolishly offensive and inflammatory hashtag, he claimed to have been calling for the death, not of white people, but of white supremacy. Online threats led him to flee the city. Academics at other campuses have been similarly harassed after distorted versions of their comments have been posted on Campus Reform (Flaherty, 2017b; Quantana, 2017b; Schmidt, 2017b). As if this were insufficient, in late 2016, a national conservative group called Turning Point created the "Professor Watchlist," the purpose of which is to "expose and document college professors who discriminate against conservative students and advance leftist propaganda in the classroom" (Flynn, 2016, para. 2). One Texas journalism professor (of some 200 on the list) was included for arguing in an essay "that deep-seated patriarchal attributes such as aggression and control have contributed to rape culture" (Flynn, 2016, para. 10; see also Reilly, 2016).

Right-wing extremist activism has escalated in Can- ada in recent years as well. In 2016, at least 100 groups committed to various forms of racism, antisemitism, white nationalism, anti-feminism, and neo-fascism were organizing across the country (Perry \& Scrivens, 2016). Although universities were not yet the main targets of these groups, their presence on campus was not unknown. In 2015, racist flyers were posted and circulated at Ryerson, York, and the University of Toronto, and subsequently at the University of Alberta, McGill University, and McMaster University (Zhou, 2017a, 2017b).

The most tragic assault by far-right activists on their ideological adversaries occurred in August 2017 in Charlottesville on the campus of the University of Virginia, where white supremacists marched and chanted fascist slogans, and where a counter-demonstrator was killed by a Nazi sympathizer (Schmidt, 2017a). The incident raises this troubling question that universities and colleges might well face: should white supremacist meetings and demonstrations be allowed on Canadian campuses? (Blumnestyk et al., 2017).

Unlike the United States, though in line with many other countries, Canada has hate speech laws (sections 318-320 of the Criminal Code) that ban speech that promotes genocide and which "incites hatred against any identifiable group where such incitement is likely to lead to a breach of the peace" (Government of Canada, 1985, p. 2; see also Government of Canada, 2021). Professors or students who engage in such actions could well be arrested, and most certainly would face sanctions and discipline on campus. Canadians, both inside and outside universities, appear more inclined than Americans to accept, as legitimate, such restraints on expression, but the scope of the law, and the definitions of "hate" and "racism," will most certainly be contested in the years ahead, as they have been in the past (McLachlin, 2004).

Against the background of free speech conflicts on campus, including a widely publicized case involving graduate student Lindsay Sheppard at Wilfrid Laurier University in 2017-she was accused by a course director of creating a toxic atmosphere in her class because she played a video clip of Jordan Peterson objecting to the compelled use of gender-neutral pronouns-the Government of Ontario took extraordinary action. In 2018, it required all universities and colleges to produce free speech policies, modelled on the University of Chicago's Statement on Principles of Free Expression, adopted in 2014, as an exemplar for Ontario, which was puzzling: why would an American institution, situated in a differ- 
ent culture and subject to different laws, be the model for shaping Ontario practice (Dea, 2018)? Nevertheless, every institution at risk of funding penalties took on the task of preparing these documents, which had to be completed in less than four months. Thereafter, each college and university was obliged to submit annual reports on free speech matters to the Higher Education Quality Council of Ontario, which has the authority to "research and evaluate how free speech is addressed at each postsecondary institution and across the postsecondary sector, as well as provide reports and recommendations to the Minister on the results of such research and evaluation" (Higher Education Quality Council of Ontario, 2020, pp. 1-2). Over the 2019-20 reporting cycle, a total of 26 complaints around free speech matters were lodged in the province's colleges and universities, and all were "resolved internally" (Higher Education Quality Council of Ontario, 2020, p. 3). How the issuing of free speech policies under this kind of government oversight will affect academic and political discourse on campus, and whether other Canadian provinces will follow suit, remains to be seen.

In what ways can the relationship of universities with government affect academic freedom? In unitary or highly centralized federal states, especially those with traditions of intervention in higher education, government edicts or regulations can play a major role in academic affairs. In Canada, a decentralized federation, where most powers over education rest with provincial governments, the role of the federal government and its agencies in university life is limited, though Ottawa does have responsibility for Canada's two military colleges, and it distributes research funds to which it regularly attaches conditions. For example, universities participating in the prestigious Canada Research Chairs (CRC) program now "must make concerted efforts to meet their equity and diversity targets," designed to increase the number of CRC scholars from designated groups: women, persons with disabilities, Indigenous peoples, and members of visible minorities (Canada Research Chairs, 2021, para. 2). No institution can allocate federal research funds to individual academics without ensuring that ethics protocols, developed by the Tri-Council federal funding agencies (covering health, engineering and science, and the social sciences and humanities), are followed. Failure to do so "may result in recourse by the agencies" (Canadian Institutes of Health Research,
Natural Sciences and Engineering Research Council of Canada, and Social Sciences and Humanities Research Council. 2018, p. 3). Ottawa thus provides opportunities for the exercise of academic freedom and prescribes the conditions under which such research support is granted, but beyond this, the federal government plays virtually no role in the governance of faculty life.

The provinces do have such power, and the regimes under which faculty work can vary across the country. Ontario, as we have seen, is the only province to have required universities to develop free speech policies, and provinces use different quality assurance protocols for the creation and regular review of academic programs (Universities Canada, 2021). Such distinctions aside, provinces, to date, have approached academic freedom in a similar way. None have moved to eliminate tenure. Notwithstanding the ritual media mocking of esoteric academic research (Brean, 2019) and the controversies roused by provocative professors (Axelrod, 2002, pp. 53-54), Canadian provincial governments have largely allowed universities to govern themselves with respect to academic culture. They have certainly imposed financial pressures that affect academic resources, they seek to ensure that universities achieve specified enrolment and access targets, and they employ accountability requirements selectively. But academic freedom is still, primarily, an institutional matter, addressed through policy and collective bargaining. If political dogmatism, intolerance, polarization, and anti-intellectualism spread in Canada, as they have elsewhere, the relative autonomy of the universities, and the freedom academics enjoy, could well be compromised and diminished.

\section{Ongoing Challenges}

Are there other constraints on expression, legitimate or otherwise, on university campuses? Contending perspectives on campus and elsewhere have arisen around the issue of cultural appropriation, most recently defined by the Oxford English Dictionary (2018) as "the unacknowledged or inappropriate adoption of the practices, customs, or aesthetics of one social or ethnic group by members of another (typically dominant) community or society" (para. 2). In 2017, when Hal Niedzvicki, the former editor of Write Magazine, seriously declared his opposition to the concept of cultural appropriation, and (less seriously) proposed a competition for a "cultural ap- 
propriation prize," he was condemned for his cultural insensitivity, and he quickly resigned his editorial position (Dundas, 2017, paras. 1, 2). His defenders were no less vocal. This was not strictly a university matter, though had Niedzvicki worked in a university, as many writers do, one can imagine that the institution would have been (and may well be in the future) caught up in such a controversy.

If cultural appropriation means that one cannot or should not teach or write outside of one's own cultural experience, then it is difficult to conceive of any reasonable notion of academic freedom that would include this restriction. By this logic, non-Aboriginal scholars would avoid research and teaching on First Nations societies, and female academics alone would pay attention, sociologically and historically, to women's lives. Among other casualties of this approach might be the discipline of history itself, for how could any of us pretend to understand earlier societies in which we did not live?

But the historical neglect, repressed voice, and caricature of First Nations, women, and other cultural groups must certainly be addressed in universities and elsewhere, which employment equity, diversified curriculum, and student service initiatives, among other programs, are all designed to address. These instruments, not those intended to regulate speech, research, or publishing, may well be the most effective ways to cultivate and sustain cultural diversity on campus.

Yet another constraint on expression: university administrators, even when they come from the ranks of faculty, are inhibited in their institutional roles in ways that the professoriate is not (Dea, 2020). Deans and vice-presidents have broader organizational responsibilities than faculty-including public relations, fundraising, and financial and human resource management-and if they publicly condemn their presidents, are perceived to be insubordinate, or discredit their universities, they can be expected to be removed. However, they are not likely to be fired. They would return to the professoriate, normally protected by tenure. When, in 2014, the Dean of Public Health at the University of Saskatchewan publicly decried budget cuts to his program, he was removed from the deanship and from his tenured position. Within one day, the latter decision was revoked; the president of the university admitted that the institution had "blundered" in firing him, though she stood by the decision to remove him from the deanship ("No excuse for what happened," 2014, para. 1; see also Sale, 2016).
Some positions in the university have both administrative and academic functions. Department chairs teach and research but also carry out certain managerial tasks. Faculty members may also head institutes designed, in part, to raise the university's profile in the community and to facilitate informed dialogue about important social issues. Controversy erupted at McGill University in 2017 when the director of the Institute for the Study of Canada, Andrew Potter, resigned after writing - by his own admission-a substandard article for Maclean's magazine that caricatured Quebec society. The university contended that in light of the article and the response to it, he could no longer effectively perform his administrative duties. His defenders accused the university of denying him his academic voice-yet another illustration of the modern complexity of academic freedom (Shingler, 2017).

The place of non-tenured or tenure-stream faculty in the academic freedom discourse is also far from straightforward. As multipurpose, financially strained institutions, many universities in Canada and the United States are now highly dependent on part-time instructors to help meet teaching needs in undergraduate and professional programs, although their exact numbers in Canada are unknown because complete data is unavailable to researchers. But, as one Ontario study observed, full-time hiring in the early 2000 s was certainly not keeping pace with enrolment growth: "the number of full-time equivalent students in Ontario universities increased by $52 \%$ during the ten-year period from 2000-2001 to 20092010, while the number of full-time tenure-stream faculty increased by only 30\%" (Field et al., 2014, p. 9). Parttime faculty, consisting of sessional instructors (those hired on a per-course basis), graduate student teaching instructors, and working professionals who contribute to clinical or classroom instruction, were an important staffing component in Ontario and elsewhere.

While their advocates, including some full-time faculty associations, have insisted that part-timers should be entitled to broad academic freedom, this is difficult to realize within the current university structure. Academic freedom is usually embedded in the tenure process, although other collective agreement provisions can secure the autonomy and protection of staff, including that of part-timers. Still, the tenuousness of their appointments is likely to limit their voice within departments which they depend upon for course-by-course appointment renewals. Their participation in the scholarly culture is also marginalized because they are not expected, and are 
not paid, to research and publish. And, as Byrne notes, part-time faculty actually enhance the academic freedom of full-timers.

The ability to cope with changing instructional needs through hiring part-timers makes it easier for institutions to continue to support tenured faculty and their research needs. Hiring adjuncts permits senior faculty to pursue their specialized interests without needing to teach basic or remedial courses or staff courses in which they have little or no intellectual interest or for which they have no aptitude, but which properly fit within the curriculum. (Byrne, 2001, p. 589)

The more universities draw on the labour of non-tenured faculty-a financial exigency (or strategy) in many jurisdictions-the larger is the component of the teaching staff that lacks full access to the privileges of academic freedom.

The principles of academic freedom can also be strained by the undue influence of corporations interested in the commercialization of university-based research. University researchers, especially in the medical, bio-chemical, and bio-technology areas, have much to offer companies interested in bringing new products to the marketplace, something that has been encouraged in recent years by governments and university leaders promoting the key role of higher education in the new knowledge economy (Laidler, 2002). While there are clear potential benefits to academic and business parties to such arrangements-the former secure research funding for major projects that might not otherwise be available, and the latter gain access to university resources (expertise, labs, research workers) - there are risks to academic autonomy if strict protocols are not established and followed. Conflicts have periodically arisen around such issues as donor influence in the appointment of university chairs or the design of curricula, and in the content and timing of publications arising out of sponsored research (Brownlee, 2016).

Possibly the most famous Canadian case in recent years that spoke to these issues involved Dr. Nancy Olivieri from the University of Toronto, whose research into the experimental drug deferprone, used in the treatment of the blood disorder thalassemia, led her to question the long-term effects of the drug on patients. A confidentiality clause that she had signed with the funder, Apotex, prevented her from publishing her critical findings without company authorization, a condition she later regretted and challenged. She subsequently lost her position as head of the haemoglobinopathy program at the Hospital for Sick Children in Toronto, though she was reinstated at the hospital following a public campaign on her behalf. The situation was complicated by the fact that Olivieri, under contract with the Hospital for Sick Children, was not a full-time faculty member and thus not a member of the University of Toronto Faculty Association. Her case, then, could not be pursued through the normal faculty grievance procedures. It was taken up, instead, by a CAUT commission of inquiry.

The inquiry found serious shortcomings in the way this dispute was handled. It recommended:

All universities should have a policy prohibiting clauses in contracts, investigator agreements or protocols restricting communication (including publication) of risks identified in research projects, particularly clinical trials. They should have procedures in place to ensure this policy is followed in practice. It is their duty to act strongly in support of their researchers if the researchers' independence or academic freedom is threatened by any sponsor. (Thompson et al., 2001, p. 18; see also Woodhouse, 2009)

Universities Canada paid some heed to these concerns in its revised 2011 Academic Freedom statement, which stated that "faculty also share with university leadership the responsibility of ensuring that pressures from funding and other types of partnerships do not unduly influence the intellectual work of the university" (Universities Canada, 2011, para. 15).

How such principles are fully employed in practice is an enduring question, addressed, if at all, by university ethics policies and collective agreements which vary from campus to campus. In a 2013 analysis of 12 agreements involving universities, donors, corporations, and governments, the CAUT found that seven of these contracts provided "no specific protection for academic freedom" (CAUT, 2013, p. 6). Some failed to provide academic researchers the right to publish work flowing from the projects, beyond a 60-day delay allowing for corporate patent applications. Nor did all of these contracts ensure access by researchers to the data they had helped produce (CAUT, 2013). In an era in which government-funded agencies not only encourage but often require university-private sector collaboration as a con- 
dition of their own financial support for research, these contractual relations warrant vigilant scrutiny to ensure that academic freedom is not undermined.

Threats to open inquiry might also be arising, allegedly, from the malevolent aims of nations seeking access to new technology developed in Canadian laboratories. In 2019, the Canadian Security Intelligence Service (CSIS) briefed Universities Canada about "potential threats to Canadian research" from "foreign agents in labs" (Friesen, 2021, para. 4) interested in artificial intelligence and quantum computing work that could have a military application. Canadian universities, "unwittingly" (Friesen, 2021, para. 21), could be important tools in an emerging cybernetic cold war. In response, international collaborative projects funded by the Natural Sciences and Engineering research Council of Canada (NSERC), are now to be closely scrutinized by CSIS for their national security implications. According to a Globe and Mail report, "CSIS says it doesn't want to hamper international scientific collaboration. It wants universities, labs and individual researchers to take more responsibility for defending against security threats" (Friesen, 2021, para. 13). Universities are now being asked by the government to "develop risk guidelines for research partnerships" (Friesen, 2021, para. 24).

Perhaps the starkest regulatory move in this area occurred in May 2021, when the provincial Government of Alberta directed its four research universities to suspend "any new partnerships with people or organizations with links to the Chinese government or its ruling party" (Johnson, 2021, para. 3). Thus, the actions taken by external actors seeking to exploit scientific research for questionable political ends, and the steps taken internally to resist such practices could, together, constrain the research environment in Canada and elsewhere (Chen et al., 2021; Johnson, 2021).

A final potential challenge to scholarly life: the impact of new social media on the theory and practice of academic freedom. This issue stirred attention in 2013 following the adoption by the University of Kansas Board of Regents of new rules designed to sanction faculty for the "improper use of social media" (Wilson, 2016, para. 8), which the American Association of University Professors called a "gross violation of the fundamental principles of academic freedom" (Wilson, 2016, para. 8). The university took action after one of its journalism professors, David Guth, posted this tweet after a lone gunman shot 12 people at the Washington Navy Yard: "The blood is on the hands of the \#NRA [National Rifle Association]. Next time let it be YOUR sons and daughters. Shame on you. May God damn you." Guth was suspended for a semester (Wilson, 2016, para. 11).

The controversy, and others that have followed, speak to several issues: do professors, using their university affiliations, have the right to pronounce on subjects on which they do not have academic expertise? Should such non-expert-even inflammatory-comments be protected under basic citizenship and civil liberties legislation (First Amendment rights in the United States; Charter of Rights and Freedoms and human rights laws in Canada)? Do universities have the right to rein in the speech of university employees who are perceived to harm the reputations of the institutions? And are social media postings on sites such as Facebook, Twitter, or Instagram different in substance from those published in conventional academic outlets such as journals, books, magazines, and newspapers?

Faculty associations, including CAUT, are unambiguous on these questions:

In posting information about their research, teaching, and intellectual interests on web sites or other electronic platforms, regardless of location or source of the host, academic staff have the same rights of academic freedom as when they present such material in speech, print and/or other media for the benefit of students, colleagues, publishers, community groups, and so on.... In expressing in electronic fora and social media their views on topics of public interest, whether or not those topics fall within their area of professional expertise, academic staff have the same rights of academic freedom as when they engage in any other form of public discourse. (CAUT, 2019, para. 4)

Notably, Universities Canada's most recent Statement on Academic Freedom made no reference to either issue: the right of professors to speak out on subjects outside their area of expertise, or their use of social media platforms (Universities Canada, 2011).

One author recommends the adoption of guidelines on faculty use of social media because of the risks involved, both for individual academics and the institutions that employ them. Social media postings, which reach mass audiences instantly, can be misused by mischief makers (texts can be altered, for example) and 
expose the authors to harassment, or worse. Such faculty postings may also have an impact on the image of a university in an era when branding and reputation-building are high priorities, and in which social media are playing an increasingly important promotional role (Cox, 2020). More clarity on the technical workings, the advantages, and the hazards of these platforms might enable academics and administrators to reconcile their use with academic freedom protocols.

\section{Conclusion}

When the Canadian Journal of Higher Education began publishing in 1971, Canadian faculty, so many of whom were recently hired, were striving to strengthen their autonomy, security, and academic freedoms, which in previous generations had been tentative at best. Much progress was made on these fronts. Academics with tenure, supported by more research funding, earned the right to explore topics that interested them, conduct classes without interference, participate in public debates, and criticize their institutions and governments.

But the circumstances under which these rights were gained, and the conditions under which they were qualified or constrained, were not static. They evolved in light of social, cultural, political, and organizational changes. Notably, the movement for greater equity on campus with respect to religion, gender, and race exposed systemic discrimination and demonstrated the legitimacy, on and off campus, of collective, as well as individual, rights. Prohibitions on racism, sexism, and harassment have become the norm and have affected, to some degree, the conduct of university relationships and the use of language. In the main, such constraints are defensible. But behavioural regulations can be too wide-ranging, ineptly applied, or taken to extremes by zealous, media-savvy advocates who seek to silence rather than intellectually engage their adversaries, a growing danger in societies where political intolerance, anti-intellectualism, and creeping authoritarianism lurk.

Furthermore, in an era when universities employ different tiers of faculty, academic freedom is a privilege enjoyed by those with tenure, less so by those without. And as post-secondary institutions seek to demonstrate their economic relevance and utility, they run the risk of conceding too much control to private contractors and research sponsors, who may favour secrecy over unfet- tered discourse, a practice inconsistent with open inquiry. Academic freedom in Canada and elsewhere is a precious historical bequest that should be protected and enriched and, as J. Percy Smith wrote in the CJHE's very first article, never taken for granted (Smith, 1971).

\section{References}

Abella, R. (1984). Equality in employment: A royal commission report. https://publications.gc.ca/collections/collection 2014/rhdcc-hrsdc/MP43-157-11984-1-eng.pdf

Axelrod, P. (1990). Making a middle class: Student life in English Canada during the 1930s. McGill-Queen's University Press.

Axelrod, P. (1995). Spying on the young in depression and war: Students, youth groups and the RCMP, 1935-1942. Labour/Le Travail, 35, 42-63. http:/l www.Iltjournal.ca/index.php/llt/article/view/4960

Axelrod, P. (1999). The ironies of academic freedom. In K. Petersen \& A. Hutchinson (Eds.), Interpreting censorship in Canada (pp. 351-366). University of Toronto Press.

Axelrod. P. (2002). Values in conflict: Universities, the marketplace, and the trials of liberal education. McGill-Queen's University Press.

Axelrod, P. (2018, January 24). Academic freedom: Can history be our guide? University Affairs. https:ll www.universityaffairs.ca/features/feature-article/ academic-freedom-can-history-guidel

Beatty, E., Sir. (1937). Freedom and the universities. Queen's Quarterly, 19(4), 463-471.

Ben-Porath, S. R. (2017). Free speech on campus. University of Pennsylvania Press.

Blumenstyk, G., Gluckman, N., \& Kelderman. (2017, August 12). When white supremacists descend, what can a president do? The Chronicle of Higher Education. https://www.chronicle.com/article/whenwhite-supremacists-descend-what-can-a-collegepresident-dol

Brean. J. (2019, June 10). Dodgeball isn't just problematic, it's an unethical tool of 'oppression': researchers. National Post. https://nationalpost.com/news/ 
dodgeball-isnt-just-problematic-its-an-unethical-tool-of-oppression-researchers

Brownlee, J. (2016). Academic inc.: How corporatization is transforming Canadian universities. Fernwood Publishing.

Brubacher, J. S., \& Rudy, W. (1976). Higher education in transition: A history of American colleges and universities. Harper and Row.

Byrne, J. P. (2001). Academic freedom of part-time faculty. Journal of College and University Law, 27(3), 583-593. https://scholarship.law.georgetown.edul facpub/1690

Cameron, D. (1991). More than an academic question: Universities, government, and public policy in Canada. Institute for Research on Public Policy.

Campbell, L., Clément, D., \& Kealey G. S (Eds.). (2012). Debating dissent: Canada and the sixties. University of Toronto Press.

Canada Research Chairs. (2021). Equity, diversity and inclusion requirements and practices. Government of Canada. https://www.chairs-chaires.gc.ca/program-programme/equity-equite/index-eng.aspx\#commitment

Canadian Association of University Teachers. (2013). Open for business: On what terms? https://www. caut.ca/sites/default/files/open-for-businessnov-2013.pdf

Canadian Association of University Teachers. (2018). Academic freedom: CAUT policy statement. https://www. caut.ca/about-us/caut-policy/lists/caut-policy-statements/policy-statement-on-academic-freedom

Canadian Association of University Teachers. (2019). Academic freedom, electronic communications and social media, policy statement. https://www.caut.cal about-us/caut-policy/lists/caut-policy-statements/ policy-statement-on-academic-freedom-and-electronic-communications

Canadian Institutes of Health Research, Natural Sciences and Engineering Research Council of Canada, and Social Sciences and Humanities Research Council. (2018). Tri-Council policy statement: Ethical conduct for research involving humans. https:/l ethics.gc.ca/eng/documents/tcps2-2018-en-interactive-final.pdf

Chase. S. (2010, April 2). Ann Coulter's speech in Ottawa cancelled. Globe and Mail. https://www. theglobeandmail.com/news/politics/ann-coultersspeech-in-ottawa-cancelled/article4352616/

Chaudry, I., \& Kennedy, M. (2020, March 1). Should universities 'de-platform' speakers? Alberta Views. https:ll albertaviews.ca/universities-deplatform-speakers/

Chen, S., Yu, H., \& Price. J. (2021, June 23). Why Alberta must rethink its ban on Canada-China university collaborations. The Conversation. https://theconversation.com/why-alberta-must-rethink-its-ban-on-canada-china-university-collaborations-161851

Clanchy, M. C. (1997). Abelard: A medieval life. Blackwell Publishers.

Courtenay, W.J. (1989). Inquiry and inquisition: Academic freedom in medieval universities. Church History, 58(2), 168-181. https://www.semanticscholar.org/paper/Inquiry-and-Inquisition\%3A-Academic-Freedom-in-Courtenay/43d7bac22dfa1fcee7e22bf922c89f68ad1a4e83

Cox, G. C. (2020). Dear professor, be careful with those tweets, ok? Academic freedom and social media. PS: Political Science \& Politics, 53(3), 521-526. https://www.cambridge.org/core/journals/ ps-political-science-and-politics/article/dear-professor-be-careful-with-those-tweets-ok-academic-freedom-and-social-media/93FEE0E38CEC954514C96222F249CFCC

Cromwell, T. A., Hon. (2020). York University independent review. York University. https://president. yorku.ca/files/2020/06/Justice-Cromwell's-Independent-External-Review.pdf

Dea, S. (2018). Free speech and the battle for the university. Academic Matters. https://academicmatters. ca/free-speech-and-the-battle-for-the-universityl

Dea, S. (2020, September 14). Learning to say goodbye to academic freedom. University Affairs. https:/l www.universityaffairs.ca/opinion/dispatches-academic-freedom/learning-to-say-goodbye-to-academic-freedom/ 
Domonkos, L. S. (1977). History of higher education. In P. Nuno Teixeras, J-C. Shin, A. Amaral, A. Bernasconi, A. M. Magalhaes, B. M. Kehn, B. Stensaker, E. Choi, E. Balbachevsky, F. Hunter, G. Goastellec, G. Mohamedbhai, H. de Wit, J. Välimaa, L. Rumbley, L. Unangst, M. Klemencic, P. Langa, R. Yang, \& T. Nokkala (Eds.), International encyclopedia of higher education (pp. 1-22). Jossey-Bass.

Drakich, J., Taylor, M., \& Bankier, J. (1995). Academic freedom is the inclusive university. In S. Richer \& L. Weir (Eds.), Beyond political correctness: Towards the inclusive university (pp. 118-135). University of Toronto Press.

Dreid, N., \& Najmabadi, S. (2016, December 13). Here's a rundown of the latest campus-climate incidents since Trump's election. The Chronicle of Higher Education. https://www.chronicle.com/blogs/ ticker/heres-a-rundown-of-the-latest-campus-climate-incidents-since-trumps-election

Dundas, D. (2017, May 10). Editor quits amid outrage after call for 'appropriation prize' in writer's magazine. Toronto Star. https://www. thestar.com/entertainment/books/2017/05/10/ editor-quits-amid-outrage-after-call-for-appropriation-prize-in-writers-magazine.html

Fallis, G. (2007). Multiversities, ideas, and democracy. University of Toronto Press.

Field, C.C., Jones, G. S., Stephenson, G. K., \& Khoyestsya, A. (2014). The other university teachers: Non full-time instructors at Ontario universities. Higher Education Quality Council of Ontario. https://heqco.ca/wp-content/uploads/2020/03/Nonfull-time-instructors-ENG.pdf

Flaherty, C. (2017a, June 1). Concession to violent intimidation. Inside Higher Education. https://www. insidehighered.com/news/2017/06/01/princetonprofessor-who-criticized-trump-cancels-events-saying-shes-received-death

Flaherty, C. (2017b, June 26). Old criticisms, new threats. Inside Higher Education. https://www. insidehighered.com/news/2017/06/26/professorsare-often-political-lightning-rods-now-are-facingnew-threats-over-their
Flynn, M. (2016, December 1). Conservative watchdogs keeping an eye on ten radical liberal professors in Texas. Houston Press. https://www.houstonpress.com/news/conservative-watchdogs-keeping-an-eye-on-10-radical-liberal-professors-in-texas-8992226

Friedland, M. (2002). The University of Toronto: A history. University of Toronto Press.

Friesen, J. (2021, July 26). CSIS warns Canadian universities to be on alert for international espionage. Globe and Mail. https://www.theglobeandmail.com/ canada/article-csis-cautions-canadian-universities-to-be-on-alert-for-international/

Gidney, C. (2012). The Canadian Association of University Teachers and the rise of faculty power, 19511971. In L. Campbell, D. Clément, \& G. S. Kealey (Eds.), Debating dissent: Canada and the sixties (pp. 67-79). University of Toronto Press.

Glenn, C. L. (2010). University mission and academic freedom: Are they in conflict? Amsterdam Law Forum, 2(3), 13-22. https://amsterdamlawforum. org/articles/abstract/10.37974/ALF.133/

Governing Council, University of Toronto. (2016). University of Toronto, faculty association, memorandum of agreement. https://governingcouncil. utoronto.ca/secretariat/policies/faculty-association-memorandum-agreement-governing-council-and-university

Government of Canada. (1985). Justice Laws Website. http://laws-lois.justice.gc.ca/eng/acts/C-46/section-318.html

Government of Canada. (2021). Department of Justice. The Canadian Charter of Rights and Freedoms, section 1. https://www.justice.gc.ca/eng/csj-sjc/rfcdlc/ccrf-ccdl/check/art1.html

Gursen, J. S. (2017, June 4). How Trump has stoked campus debate on speech and violence. The New Yorker. https://www.newyorker.com/news/newsdesk/how-trump-has-stoked-the-campus-debate-onspeech-and-violence

Harris, K. (2018, June 15). Trinity Western loses fight for Christian law school as court rules limits on religious freedom 'reasonable.' CBC News. https:ll 
www.cbc.ca/news/politics/trinity-western-supreme-court-decision-1.4707240

Hewitt, S. (2002). Spying 101: The RCMP's secret activities in Canadian universities, 1917-1997. University of Toronto Press.

Higher Education Quality Council of Ontario. (2020). Freedom of speech on campus: Annual report to the Ontario government. https://heqco. ca/wp-content/uploads/2020/12/FINAL-HEQCO-Free-Speech-on-Campus-Annual-Report-to-Government-December-2020.pdf

Horn, M. (1980). The league for social reconstruction: Intellectual origins of the democratic left in Canada. University of Toronto Press.

Horn. M. (1999). Academic freedom in Canada: A history. University of Toronto Press.

Johnson, L. (2021, May 26). Alberta government orders suspension of new university research links with China. Edmonton Journal. https:/l edmontonjournal.com/news/politics/alberta-government-orders-suspension-of-new-university-research-with-links-to-chinese-government

Jordan Peterson protest at Queen's University: Lock 'em in and burn it down. (2020, March 5). [Video]. YouTube. https://www.youtube.com/watch?v=xPyPSyM3B3c

Kaufman, E. (2020, September 21). The denial of cancel culture. Quillette. https://quillette. com/2020/09/01/the-denial-of-cancel-culturel

Kimball, B. (1995). Orators and philosophers: A history of the idea of liberal education. College Entrance Examination Board.

Kymlicka, W. (1995). Multicultural citizenship: A liberal theory of minority rights. Oxford University Press.

Laidler, D. (2002). (Ed.) Renovating the ivory tower: Canadian universities and the knowledge economy. C.D. Howe Institute.

Locke, J. (2006). An essay concerning toleration: And other writings on law and politics, 1667-1683. Clarendon Press.

MacKinnon, P. (2018). University commons divided (pp.
75-89). University of Toronto Press.

McLachlin, B. (2004). Protecting constitutional rights: A comparative view of Canada and the United States. Remarks of the Honourable Beverley McLachlin, P.C., Chief Justice of Canada. Centre for the Study of Canada. https://www.scc-csc.ca/judges-juges/ spe-dis/bm-2004-04-05-eng.aspx

Montreal protesters force cancellation of Netanyahu's speech. (2002, September 10). CBC News. https://www.cbc.ca/news/canada/montreal-protesters-force-cancellation-of-netanyahu-speech-1.312529

'No excuse for what happened': University of Saskatchewan concedes it 'blundered' when it fired prof Robert Buckingham. (2014, January 25). Star Phoenix/National Post. https://nationalpost.com/ news/canada/no-excuse-for-what-happened-university-of-saskatchewan-concedes-it-blundered-whenit-fired-prof-robert-buckingham

Nussbaum, M. (1997). Cultivating humanity: A classical defence of reform in liberal education. Harvard University Press.

Oxford English Dictionary. (2018). New words notes. In oed.com dictionary. https://public.oed.com/blog/ march-2018-new-words-notes/

Perry, B., \& Scrivens, R. (2016). Uneasy alliances: A look at the right-wing extremist movement in Canada. Studies in Conflict and Terrorism, 39(9), 819-841. https://www.tandfonline.com/doi/abs/10.1 080/1057610X.2016.1139375

Quantana, C. (2017a, April 27). At Berkeley, a speaker's cancellation spurs new battles over free speech. The Chronicle of Higher Education. https://www. chronicle.com/article/at-berkeley-a-speakers-cancellation-spurs-new-battles-over-free-speech/

Quantana, C. (2017b, June 21). Trinity College of Conn. closes over threats after conservative website targets professor. The Chronicle of Higher Education. https://www.chronicle.com/blogs/ticker/trinity-college-of-conn-closes-over-threats-after-conservative-website-targets-professor

Reilly, K. (2016, December 1). Professors targeted by conservative watchlist fire back: It's obviously 
an attempt to silence people. Time. https://time. com/4588165/professor-watchlist-silence-conservativel

Robinson, D. (2019). Academic freedom in Canada: $A$ labour law right. American Association of University Professors. https://www.aaup.org/article/academic-freedom-canada-labor-law-right\#.YOuPBSOZPzI

Rogers, R., Taylor, J., \& McKelvey, S. (2018, March 1). Canada: An update on freedom of expression \& charter application to universities. Mondaq. https:// www.mondaq.com/canada/education/678606/ an-update-on-freedom-of-expression-charter-application-to-universities

Sale, C. (2016). "By whose definition?" The University of Saskatchewan's firing of a dean and the textual battle to define academic freedom in Canada. Journal of Historical Sociology, 29(1), 23-41. https:/l onlinelibrary.wiley.com/doi/abs/10.1111/johs.12123

Schmidt, P. (2017a, August 15). Charlottesville violence sparks new concerns about safety during campus protests. The Chronicle of Higher Education. https://www.chronicle.com/article/charlottesville-violence-sparks-new-worries-about-safety-during-campus-protests/

Schmidt, P. (2017b, June 22). Professors' growing risk: Harassment for things they never really said. The Chronicle of Higher Education. https://www. chronicle.com/article/professors-growing-risk-harassment-for-things-they-never-really-said/

Shingler, B. (2017, March 23). Andrew Potter resigns from post after Maclean's article on Quebec. CBC News. https://www.cbc.ca/news/canada/montreal/ andrew-potter-mcgill-institute-for-the-study-of-canada-resignation-macleans- 1.4037618

Smith, J. P. (1971). What matters academic freedom? Canadian Journal of Higher Education, 1(1), 5-13. https://journals.sfu.ca/cjhe/index.php/cjhe/article/ view/1-5

Taylor, C. (1994). On recognition. In W. Kymlicka (Ed.), Multicultural citizenship: A liberal theory of minority rights (pp. 25-74). Oxford University Press.

Thompson, J., Baird, P., \& Downie, J. (2001). The Olivieri report: The complete text of the report of the independent inquiry commissioned by the Canadian Association of University Teachers. James Lorimer \& Company.

Thrasher, S. W. (2017, June 5). Yes, there is a free speech crisis. But its victims are not white men. The Guardian. https://www.theguardian.com/ commentisfree/2017/jun/05/free-speech-advocatsblack-women-silenced

Tiede, H. J. (2015). University reform: The founding of the American Association of University Professors. Johns Hopkins University Press.

Universities Canada. (2011, October 25). Statement on academic freedom [Press release]. https://www. univcan.ca/media-room/media-releases/statement-on-academic-freedom/

Universities Canada. (2021). The role of universities in quality assurance. https://www.univcan.cal universities/quality-assurance/the-role-of-universities-in-quality-assurance/

Wilson, J. K. (2016). The changing media and academic freedom: The impact of social media on the faculty. American Association of University Professors. https://www.aaup.org/article/changing-media-and-academic-freedom\#.X9zHpSOZN24

Woodhouse, H. (2009). Selling out: Academic freedom and the corporate marketplace. McGill-Queen's University Press.

Zhou, S. (2017a). Canada's university administrators must pay attention to right-wing activism on campuses. Academic Matters. https://academicmatters. ca/assets/AcademicMatters-Spring2017.pdf

Zhou, S. (2017b, January 15). Canadian campuses see an alarming rise in right-wing populism. CBC News. https://www.cbc.ca/news/canada/manitoba/ opinion-campus-right-wing-populism-1.3932742

\section{Contact Information}

Paul Axelrod paxelrod@edu.yorku.ca 


\section{Notes}

1 Portions of this article appeared first in University Affairs (Axelrod, 2018).

2 In 2014, Ontario's Law Society of Upper Canada voted to deny accreditation to graduates from Trinity Western's proposed law program on the grounds that the university discriminated against LGBTQ persons, and the Ontario Court of Appeal upheld the Law Society's decision, as did the Supreme Court of Canada in a 2018 decision (Harris, 2018).

3 Whether the Charter of Rights and Freedoms actually applies to universities is an ongoing and largely unresolved legal question. Charter provisions pertain to governments and government agencies. Many universities in Canada, including those that are publicly assisted, have private charters (Rogers et al., 2018).

4 The Canadian Charter of Rights and Freedoms also limits "fundamental freedoms," such as freedom of expression, so long as these limits can be "demonstrably justified in a free and democratic society" (Government of Canada, 2021, para. 1). 